\title{
Evaluation of prenatal ultrasonographic markers in aneuploidy cases
}

\author{
Orkun Çetin, Fatma Ferda Verit Atmaca, Ayşegül Deregözü, Ali Galip Zebitay, Oğuz Yücel \\ Clinics of Gynecology\&Obstetrics, Siileymaniye Maternity Training and Research Hospital, Istanbul, Turkey
}

\begin{abstract}
Objective: The aim of our study is to evaluate the major structural anomalies and minor ultrasonographic markers in aneuploidy cases of our clinic.

Methods: Between the January 2008 and July 2012, 1517 cases that had genetic amniocentesis were analyzed. Fifty-three cases with proven aneuploidy were evaluated from cytogenetic records of fetuses. The ultrasonographic findings of aneuploidic fetuses found during fetal anomaly screening at 18-22 weeks of gestation were analyzed.

Results: Thirty-five of 53 aneuploidic fetuses which were included in the study were trisomy 21,7 of them were trisomy 18,2 of them were trisomy 13, 6 of them were 47,XXY (Klinefelter syndrome), and 3 of them were $45, \mathrm{X}$ (Turner syndrome). The most frequently observed minor ultrasonographic marker in trisomy 21 cases was increased nuchal thickness. Most commonly seen major structural anomaly in trisomy 18 cases was hydrops fetalis while it was hyperechogenic intracardiac focus in trisomy 13 cases.

Conclusion: Ultrasonography usage in the diagnosis of fetuses with chromosomal anomaly gradually increases. Invasive prenatal test should be suggested to the family in the presence of serious structural anomalies or in the existence of several ultrasonographic findings.

Key words: Aneuploidy, fetal ultrasonography, major structural anomaly.
\end{abstract}

\section{Introduction}

Chromosomal anomalies are one of the most significant reasons of fetal morbidity and mortality. Invasive prenatal diagnostic procedures are used for the diagnosis of fetal aneuploidy. These diagnosis methods are

\section{Anöploidi olgularının prenatal ultrasonografik belirteçlerinin değerlendirilmesi}

Amaç: Çalışmamızın amacı; kliniğimizde anöploidi saptanan olgularda majör yapısal anomalilerin ve minör ultrasonografik belirteçlerin değerlendirilmesidir.

Yöntem: Ocak 2008 - Temmuz 2012 tarihleri arasında genetik amniyosentez incelemesi yapılan 1517 olgu incelendi. Fetüslere ait sitogenetik kayıtlardan anöploidi saptanan 53 olgu değerlendirmeye alındı. Anöploidisi olan fetüslerin 18-22 gebelik haftalarında yapılan fetal anomali taramasında saptanan ultrasonografik bulguları gözden geçirildi.

Bulgular: Çalışmaya dahil edilen 53 anöploidik fetüsün 35'i trizomi 21, 7'si trizomi 18, 2'si trizomi 13, 6's1 47,XXY Klinefelter sendromu, 3’ü 45,X Turner sendromu olarak rapor edilen olgulardi. Trizomi 21 olgularında en sık izlenen minör ultrasonografik belirteç artmış ense kalınlığıydı. Trizomi 18 olgularında en sık majör yapısal anomali hidrops fetalis olarak karşımıza çıktı. Trizomi 13 olgularında en sık kalpte hiperekojen odak izlendi.

Sonuç: Kromozom anomalili fetusların tanısında ultrasonografinin kullanımı giderek artmaktadır. Fetusta ciddi yapısal anomali varlığında veya birden fazla ultrasonografik bulgu varlığında aileye invaziv prenatal test önerilmelidir.

Anahtar sözcükler: Anöploidi, fetal ultrasonografi, majör yapısal anomali.

recommended only to pregnants who have high risk of chromosomal anomaly since they may progress with pregnancies resulting with $1-2 \%$ high miscarriage rates. ${ }^{[1]}$ Another method to determine pregnants in high risk group is the second trimester ultrasonographic evaluation. This evaluation should be able to
Correspondence: Orkun Çetin, MD. Süleymaniye Doğumevi Eğitim ve Araştırma Hastanesi Kadın Hastalıkları ve Doğum Kliniği, İstanbul, Turkey e-mail: drorkuncetin34@hotmail.com

Received: June 15, 2013; Accepted: August 17, 2013
Available online at: www.perinataljournal.com/20130213005 doi: $10.2399 /$ prn.13.0213005 QR (Quick Response) Code: 
research abnormal ultrasonographic findings including both major structural anomalies and minor (moderate) markers that will distinguish euploid fetuses from aneuploidic fetuses. ${ }^{[2]}$ Ultrasonographic findings of chromosomal anomalies can be listed as ventriculomegaly, holoprosencephaly, choroid plexus cyst, DandyWalker complex, cleft palate and lip, micrognathia, nasal hypoplasia, nuchal edema, cystic hygroma, diaphragmatic hernia, cardiac defects, duodenal atresia, short extremities, clinodactyly, polydactyly, and syndactyly. ${ }^{[3]}$

The purpose of our study is to evaluate in our clinic the major structural anomalies and minor ultrasonographic markers in cases found to be aneuploidic.

\section{Methods}

Totally 1517 cases that undergone genetic amniocentesis between January 2008 and July 2012 were evaluated. Fifty-three cases who found to be aneuploidic by cytogenetic records of fetuses were included to the study. Amniocentesis indications were chromosomal abnormality history in the family, advanced maternal age, high risk at screening tests, some markers found in ultrasonographic examinations, and structural anomalies. Ultrasonographic findings of aneuploidic fetuses which were detected during fetal anomaly screening at 18-22 weeks of gestation were reviewed. Babies lost at early periods, and those without karyotype analysis were excluded from the study. Ultrasonographic examinations were done by the specialists in our clinic via Voluson 730 Expert ultrasound device and 3.5 MHz probe. Amniocentesis procedure was carried out in company with ultrasonography after abdominal region was cleaned twice by octenidine hydrochloride through 22-gauge spinal needle. Twenty metaphases were expected at least in 5 cultures. Detecting same chromosomal defect in two different cell cultures on more than two cells was considered as mosaicism. During ultrasonographic examination, head, face, neck, thorax (image of atriums and ventricles, and major vessel outlets), abdominal cavity, extremities (hands and feet), spinal cord, long bones, and genital area of fetuses were evaluated. Abnormalities of each organ were recorded. As ultrasonographic marker definitions, nuchal skin thickness being $6 \mathrm{~mm}$ or thicker, existence of choroid plexus cysts at any number and size on cerebral ventricles, echogenicity increase in cardiac ventricle, and renal pelvis diameter exceeding 4 $\mathrm{mm}$ were considered as renal pelvicaliectasis while femur and humerus lengths being 0.85 shorter than expected length was considered as short femur and humerus. Major structural anomalies were determined as central nervous system anomalies, cardiac defects, abdominal anomalies, renal anomalies, extremity anomalies, cystic hygroma, fetal hydrops and facial anomalies.

\section{Results}

The mean age of 53 patients who undergone ultrasonographic examination was 32.5 (range: 17-44) years, mean weeks of gestation was 19.9 (range: 18-23) weeks. Thirty-five $(66.03 \%)$ of 53 aneuploidic fetuses included to the study were reported to have trisomy 21 , $7(13.2 \%)$ of them were trisomy $18,2(3.77 \%)$ of them were trisomy $13,6(11.32 \%)$ of them were $47, \mathrm{XXY}$ Klinefelter syndrome, and $3(5.66 \%)$ of them were 45, X Turner syndrome (Table 1).

Totally 35 trisomy 21 cases were detected. No anomaly was detected ultrasonographically in 15 $(42.85 \%)$ of these cases. One or more major and/or minor ultrasonographic anomalies were detected in 20 cases $(57.14 \%)$. Nine of them were major structural anomaly while 28 of them were ultrasonographic markers. In three cases, major structural anomalies and minor ultrasonographic markers were observed together. Cardiovascular system anomaly seen in 5 cases $(14.28 \%)$ was the most common major structural anomaly. Ventricular septal defect was detected in 4 out of 5 cases $(11.42 \%)$. As the second most frequently observed anomaly, central nervous system anomaly was found in 4 cases $(11.42 \%)$. The most frequently seen minor ultrasonographic marker in trisomy 21 cases was the increased nuchal thickness which was seen in $20 \%$ of them $(7 / 35)$. Short femur and short humerus was seen in 6 cases $(17.14 \%)$ while nasal hypoplasia was seen in 5 cases $(14.28 \%)$, and pelvicaliectasis was seen in 4 cases $(11.42 \%)$ (Table 2$)$.

Table 1. The distribution of aneuploidy cases.

\begin{tabular}{lc} 
Anomaly & Case number \\
\hline Trisomy 21 & $35(66.03 \%)$ \\
Trisomy 18 & $7(13.2 \%)$ \\
Trisomy 13 & $2(3.77 \%)$ \\
$45, X$ & $3(5.66 \%)$ \\
$47, X X Y$ & $6(11.32 \%)$ \\
\hline
\end{tabular}


In our study, there were seven trisomy 18 cases. All cases had ultrasonographic marker. The most common major structural anomaly detected was hydrops fetalis $(42.85 \%)$. Following hydrops fetalis, cardiovascular system anomalies and central nervous system anomalies were the next common anomalies which were seen in $28.27 \%$ of the cases. Among cardiovascular system anomalies, there was ventricular septal defect in one case (14.28), and coarctation of aorta in 2 cases (14.28\%). As central nervous system anomaly, there was ventriculomegaly in 2 cases $(28.57 \%)$. Choroid plexus cysts in 2 cases $(28.57 \%)$ and pelvicaliectasis in 2 cases $(28.57 \%)$ were the most common minor markers (Table 2).

In our study, trisomy 13 was detected in 2 cases. All these cases had ultrasonographic markers. Also, all cases had hyperechogenic intracardiac focus. In one case, face anomaly (cleft lip) accompanied to this anomaly, and hyperechogenic intestine accompanied in another case (Table 2).

We found Turner syndrome in 3 cases in our study. Ultrasonographic anomaly was detected in all of the cases. Also cystic hygroma was seen in all cases. In addition to cystic hygroma, hyperechogenic intestine was found in one case (Table 2).

We detected Klinefelter syndrome in 6 cases in our study. In one of these cases $(16.66 \%)$ had major structural anomaly and 5 of them $(83.33 \%)$ had minor ultrasonographic marker. Only one case had no ultrasonographic finding. We found ventricular septal defect in one case $(16.66 \%)$ as major structural anomaly. Pes equinovarus was seen in 3 cases $(66.66 \%)$ as the most common minor ultrasonographic marker. It was followed by the hyperechogenic intracardiac focus, hyperechogenic intestine and pelvicaliectasis, each seen in two cases $(33.33 \%)$ (Table 2 ).

\section{Discussion}

Chromosomal anomalies are seen in every $0.1 \%$ to $0.2 \%$ live birth. ${ }^{[4,5]}$ In our study, we analyzed 53 aneuploidy cases (3.49\%) among 1517 amniocenteses conducted for different indications. Abnormal ultrasound findings were found in 37 (69.81\%) out of 53 aneuploidic cases.

The most common structural anomalies in fetuses with trisomy 13 are the mid-facial line defects. ${ }^{[6]}$ In our study, although case number was insufficient (totally two trisomy 13 cases), cleft lip was found in $50 \%$ of cases. Nyberg and Souter indicated in their study performed on trisomy 13 cases that the central nervous system anomalies were the most common major structural anomaly, and hyperechogenic intracardiac focus was the most common minor ultrasonographic marker. ${ }^{[7]}$ In our study, hyperechogenic intracardiac focus was detected in all trisomy 13 cases. Taslimi et al. reported in their study that the possibility to detect an ultrasonographic finding after 18 weeks of gestation at second trimester increased $22.2 \%$ (from $43.7 \%$ to $64.5 \%){ }^{[8]}$ In our study, mean weeks of gestation for ultrasonographic examination was 19.9. Although these weeks of gestation have high chance for detecting ultrasonographic marker, they are late weeks of gestation in case of a medical evacuation.

Table 2. Prevalence of ultrasonographic markers in aneuploidic cases.

\begin{tabular}{|c|c|c|c|c|c|}
\hline Anomaly & Trisomy 21 & Trisomy 18 & Trisomy 13 & $47, X X Y$ & $45, X$ \\
\hline Choroid plexus cyst & $3(8.57 \%)$ & $2(28.57 \%)$ & - & - & - \\
\hline Ventriculomegaly & $2(5.71 \%)$ & $2(28.57 \%)$ & - & - & - \\
\hline Ventricular septal defect & $4(11.42 \%)$ & $2(28.57 \%)$ & - & $1(16.66 \%)$ & - \\
\hline Hyperechogenic intracardiac focus & $3(8.57 \%)$ & - & $2(100 \%)$ & $2(33.33 \%)$ & - \\
\hline Increased nuchal thickness & $7(20 \%)$ & - & - & - & - \\
\hline Hyperechogenic intestine & - & $1(14.28 \%)$ & $1(50 \%)$ & $2(33.33 \%)$ & $1(33.33 \%)$ \\
\hline Short femur-humerus & $6(17.14 \%)$ & $2(28.57 \%)$ & - & - & - \\
\hline Pelvicaliectasis & $4(11.42 \%)$ & $1(14.28 \%)$ & - & $2(33.33 \%)$ & - \\
\hline Nasal hypoplasia & $5(14.28 \%)$ & - & - & - & - \\
\hline Hydrops fetalis & - & $3(42.85 \%)$ & - & - & - \\
\hline Pes equinovarus & - & - & - & $3(50 \%)$ & - \\
\hline Single umbilical artery & - & - & - & $1(16.66 \%)$ & - \\
\hline Cystic hygroma & - & - & - & - & $3(100 \%)$ \\
\hline
\end{tabular}


Major or minor ultrasonographic anomaly was detected in all trisomy 18 cases in our study. In the study of DeVore where second trimester ultrasonographic findings of trisomy 18 cases were analyzed, non-cardiac anomalies (77\%) were found to be more common than cardiac anomalies. ${ }^{[9]}$ In our study, hydrops fetalis was the most common major structural anomaly in trisomy 18 cases. It is followed by cardiovascular system and central nervous system anomalies. Given the minor ultrasonographic markers, choroid plexus cysts were the most common ultrasound finding in trisomy 18 cases. In all trisomy 18 cases, choroid plexus cysts were accompanied by pelvicaliectasis. In the meta-analysis of Yoder et al., it was found that trisomy 18 risk increased 13.8 times in fetuses which found to have isolated choroid plexus cyst in second trimester ultrasonography. ${ }^{[10]}$ Also, amniocentesis was suggested to patients with isolated choroid plexus cyst only when maternal age was above 36 , and trisomy 18 risk was found to be high in fetal screening tests (higher than $1 / 3000){ }^{[8]}$

In our study, abnormalities were found in ultrasonographic examination in all cases with Turner syndrome. The reason for this high rate is that the phenotypic findings of cases with Turner syndrome were as severe as much to detect during first and early second trimesters ultrasonographically. ${ }^{[11]}$ The most common major structural anomaly seen in the cases with Turner syndrome is cystic hygroma as seen in our study.

Down syndrome (trisomy 21) is in the primary chromosome anomaly that perinatologists research carefully due to its possibility (1.41 per 1000 live births). ${ }^{[12]}$ Even though various rates were reported in different studies, it was reported that structural anomalies were detected in second trimester ultrasonographic examination almost $30 \%$ of fetuses with Down syndrome..$^{[13-15]}$

According to meta-analysis results of SmithBindman et al., increased nuchal thickness is the most significant ultrasonographic marker for distinguishing fetuses with Down syndrome from those without Down syndrome. ${ }^{[16]}$ It was reported that increased nuchal thickness increases trisomy 21 risk 17 times more. In our study, increased nuchal thickness was the most common minor ultrasonographic marker (20\%) in trisomy 21 cases. There were major structural anomalies in 9 fetuses $(25.71 \%$ ) with trisomy 21 . In the study of DeVore and Romero, this rate was found to be between $20 \%$ and $87 \%$, and relatively higher rate was reported compared to our study. ${ }^{[17]}$ The reason is that the cardiovascular system anomalies were at a higher rate in DeVore and Romero's study than our study. In the study of Papp et al., major structural anomaly rate was reported as $28.5 \%$ and cardiovascular system anomalies were reported as the most common major structural anomalies. ${ }^{[18]}$ This study was the most similar study for both major structural anomaly prevalence and the most common anomaly that we should research. Kallen et al. performed a postnatal series of study on fetuses with Down syndrome and reported ventricular septal defect rate as high as $28 \% .{ }^{[19]}$ In our study, ventricular septal defect rate was found to be $11.42 \%$ (4 cases).

Hypoplasia or lack of nasal bone in fetuses with Down syndrome is also a common marker. Bromley et al. reported this rate as $43 \% .{ }^{[20]}$ In a study performed by Taner et al. in Turkey, this rate was found as $10.52 \% .{ }^{[21]}$ We found the rate of hypoplasia or lack of nasal bone as $14.28 \%$ in our study. This rate was consistent with the study of Taner et al.

Klinefelter syndrome $(47, \mathrm{XXY})$ is seen in prenatal diagnostic series with a rate of $0.15 \% .{ }^{[2]}$ Klinefelter syndrome is caused by the lack of specific prenatal malformations, and establishing prenatal diagnosis by chance. ${ }^{[23]}$ In the study of Grunchy et al., it was reported that oligohydramnios, bilateral renal agenesia and congenital cardiac anomalies were the most common anomalies seen in non-mosaic 47, XXY cases. ${ }^{[24]}$ Although the case number in our study was not sufficient (6 cases with Klinefelter syndrome), the most common malformation in our study was the pes equinovarus anomaly. When other malformations are analyzed, ventricular septal defect was seen as major structural anomaly while hyperechogenic intracardiac focus, pelvicaliectasis and hyperechogenic intestine were seen as minor anomalies. The variety of anomalies detected prenatally was consistent with the literature.

Retrospective planning of our study, low number of cases with aneuploidy, not performing ultrasonographic examination by same physician each time can be all listed as the disadvantages of our study. Ultrasonographic examination at 11 and 13 weeks of gestation and maternal serum markers help diagnosis at a rate of $95 \%$ in terms of chromosomal anomalies. ${ }^{[25]}$ Determining the frequency of particular markers for 
each karyotype anomaly would be helpful in aneuploidy screening.

Trisomy 13 and trisomy 18 are the aneuploidies providing sonographic findings at a high rate. Therefore, second trimester obstetric ultrasonography seems to be helpful for detecting trisomy 13 and trisomy 18. Sonographic markers cannot be detected in a considerable part of trisomy 21 cases. Therefore, using first and second trimester biochemical screening tests together with sonographic findings will increase the possibility to detect structural chromosomal anomalies.

\section{Conclusion}

Ultrasonography usage in the diagnosis of fetuses with chromosomal anomaly gradually increases. Invasive prenatal test should be suggested to the family in the presence of serious structural anomalies or in the existence of several ultrasonographic findings.

Conflicts of Interest: No conflicts declared.

\section{References}

1. Scott F, Peters H, Boogert T, Robertson R, Anderson J, McLennan A, et al. The loss rates for invasive prenatal testing in a specialised obstetric ultrasound practice. Aust N Z J Obstet Gynaecol 2002;42:55-8.

2. Nyberg DA, Souter VL. Sonographic markers of fetal aneuploidy. Clin Perinatol 2000;27:761-89.

3. Nikolaides KH, Sebire NJ, Snijders RJM. 11-14 Week Scan Diagnosis of Fetal Abnormalities. New York: Parthenon; 1999.

4. Adams MM, Erickson JD, Layde PM, Oakley GP. Down's syndrome. Recent trends in the United States. JAMA 1981;246:758-60.

5. The California Expanded AFP Screening Program: Prenatal Care Provider Handbook. Berkeley, CA: The California Expanded AFP Screening Program; 1997.

6. McGahan JP, Nyberg DA, Mack LA. Sonography of facial features of alobar and semilobar holoprosencephaly. AJR Am J Roentgenol 1990;154:143-8.

7. Nyberg DA, Souter VL. Sonographic markers of fetal trisomies: second trimester. J Ultrasound Med 2001;20:655-74.

8. Taslimi MM, Acosta R, Chueh J, Hudgins L, Hunter K, Druzin ML, et al. Detection of sonographic markers of fetal aneuploidy depends on maternal and fetal characteristics. J Ultrasound Med 2005;24:811-5.

9. DeVore GR. Second trimester ultrasonography may identify 77 to $97 \%$ of fetuses with trisomy 18 . J Ultrasound Med 2000;19:565-76.
10. Yoder PR, Sabbagha RE, Gross SJ, Zelop CM. The secondtrimester fetus with isolated choroid plexus cysts: a metaanalysis of risk of trisomies 18 and 21. Obstet Gynecol 1999;93(5 Pt 2):869-72.

11. Shields LE, Carpenter LA, Smith KM, Nghiem HV. Ultrasonographic diagnosis of trisomy 18: is it practical in the early second trimester? J Ultrasound Med 1998;17:327-31.

12. Wright DE, Bray I. Estimating birth prevalence of Down's syndrome. J Epidemiol Biostat 2000;5:89-97.

13. Rotmensch S, Liberati M, Bronshtein M, SchoenfeldDimaio M, Shalev J, Ben-Rafael Z, et al. Prenatal sonographic findings in 187 fetuses with Down syndrome. Prenat Diagn 1997;17:1001-9.

14. Vintzileos AM, Egan JF. Adjusting the risk for trisomy 21 on the basis of second-trimester ultrasonography. Am J Obstet Gynecol 1995;172:837-44.

15. Nyberg DA, Resta RG, Luthy DA, Hickok DE, Mahony BS, Hirsch JH. Prenatal sonographic findings of Down syndrome: review of 94 cases. Obstet Gynecol 1990;76(3 Pt 1):370-7.

16. Smith-Bindman R, Hosmer W, Feldstein VA, Deeks JJ, Goldberg JD. Second-trimester ultrasound to detect fetuses with Down syndrome: a meta-analysis. JAMA 2001;285:104455.

17. DeVore GR, Romero R. Combined use of genetic sonography and maternal serum triple-marker screening: an effective method for increasing the detection of trisomy 21 in women younger than 35 years. J Ultrasound Med 2001;20:645-54.

18. Papp C, Szigeti Z, Tóth-Pál E, Hajdú J, Joó JG, Papp Z. Ultrasonographic findings of fetal aneuploidies in the second trimester--our experiences. Fetal Diagn Ther 2008;23:10513.

19. Källén B, Mastroiacovo P, Robert E. Major congenital malformations in Down syndrome. Am J Med Genet 1996;65:160-6.

20. Bromley B, Lieberman E, Shipp TD, Benacerraf BR. Fetal nose bone length: a marker for Down syndrome in the second trimester. J Ultrasound Med 2002;21:1387-94.

21. Taner CE, Aygören MO, Kayar İ, Derin G. Down sendromlu olgularda ultrasonografik bulgular. Perinatoloji Dergisi 2009; 17:65-9

22. Lanfranco F, Kamischke A, Zitzmann M, Nieschlag E. Klinefelter's syndrome. Lancet 2004;364(9430):273-83.

23. Marteau TM, Nippert I, Hall S, Limbert C, Reid M, Bobrow M, et al.; DADA Study Group. Outcomes of pregnancies diagnosed with Klinefelter syndrome: the possible influence of health professionals. Prenat Diagn 2002;22:562-6.

24. Gruchy N, Vialard F, Decamp M, Choiset A, Rossi A, Le Meur N, et al. Pregnancy outcomes in 188 French cases of prenatally diagnosed Klinefelter syndrome. Hum Reprod 2011;26:2570-5.

25. Biggio JR Jr. First trimester ultrasound screening for fetal aneuploidy and middle cerebral artery Doppler assessment for fetal alloimmunization. Curr Opin Pediatr 2005;17:713-9. 